\title{
Data, Information, Knowledge, Wisdom (DIKW): A Semiotic Theoretical and Empirical Exploration of the Hierarchy and its Quality Dimension
}

\author{
Saša Baškarada \\ University of South Australia \\ baskarada@gmail.com \\ Andy Koronios \\ University of South Australia \\ andy.koronios@unisa.edu.au
}

\begin{abstract}
What exactly is the difference between data and information? What is the difference between data quality and information quality; is there any difference between the two? And, what are knowledge and wisdom? Are there such things as knowledge quality and wisdom quality? As these primitives are the most basic axioms of information systems research, it is somewhat surprising that consensus on exact definitions seems to be lacking. This paper presents a theoretical and empirical exploration of the sometimes directly quoted, and often implied Data, Information, Knowledge, Wisdom (DIKW) hierarchy and its quality dimension. We first review relevant literature from a range of perspectives and develop and contextualise a theoretical DIKW framework through semiotics. The literature review identifies definitional commonalities and divergences from a scholarly perspective; the theoretical discussion contextualises the terms and their relationships within a semiotic framework and proposes relevant definitions grounded in that framework. Next, rooted in Wittgenstein's ordinary language philosophy, we analyse 20 online news articles for their uses of the terms and present the results of an online focus group discussion comprising 16 information systems experts. The empirical exploration identifies a range of definitional ambiguities from a practical perspective.
\end{abstract}

Keywords: data, information, knowledge, wisdom, DIKW hierarchy, quality, semiotics, Wittgenstein, ordinary language philosophy

\section{INTRODUCTION}

There is a growing concern ... about the present situation, where too many fuzzy or ill-defined concepts are used in the information system area. Scientific as well as practice-related communication is severely distorted and hampered, due to this fuzziness and due to the frequent situation that different communication partners associate different meanings with one and the same term. There is no commonly accepted conceptual reference and terminology, to be applied for defining or explaining existing or new concepts for information systems (Falkenberg et al., 1998, p. 2).

Whilst the above quotation dates back to the previous century, its message is still as relevant as ever (Weinberger, 2010). The highly-abstract language currently used to describe some of the key information systems constructs can be difficult to understand and is potentially at risk of becoming meaningless (Shields, 2001). Accordingly, it has been argued that the information systems 
community "has to uncover, through hermeneutic interpretation and analysis, the fundamental nature of its discipline” (O'Donovan and Roode, 2002, p. 34).

Information systems are socio-technical communication systems that use artefacts to represent and transmit data (Beynon-Davies, 2009a, Allen, 2000, Claver et al., 2001). They have existed for thousands of years, long before the advent of modern information and communications technologies. For instance, the Inca civilisation operated an effective information system without utilising a written language; they recorded complex messages on coloured, knotted, cotton cords (Beynon-Davies, 2007). The Data, Information, Knowledge, Wisdom (DIKW) hierarchy (see Figure 1), also referred to as the knowledge hierarchy, the information hierarchy, and the knowledge pyramid (Rowley, 2007, p. 163) forms the foundation of information systems research. While the hierarchy itself is often quoted, and explicitly or implicitly applied in the information systems literature (information is usually defined in terms of data, knowledge in terms of information, and wisdom in terms of knowledge) there has been limited direct discussion of the content and the structure of the hierarchy (Zins, 2011). The concept of wisdom in particular has received very limited discussion in the literature (Rowley, 2007).

Since only limited consensus regarding definitions has been reached, the terms as well as their relationships remain ambiguous (Chen et al., 2009, Aamodt and Nygård, 1995, Stenmark, 2002, Shields, 2001, Hasan, 2002). For instance, the terms data and information are often used synonymously; e.g. data management and information management (Chen et al., 2009). Similarly, in the context of data mining, knowledge has been equated with useful information, and described as pattern that exceeds some threshold determined by the user (Fayyad et al., 1996). On the other hand, it has also been argued that, data is not information and that information is not knowledge (Chen et al., 2009, Kallinikos, 2006, Kamhawi, 2010).

Given the definitional challenges involved, it has even been suggested that it is "beyond the scope of computer science as a discipline to provide a general definition of these terms" (Aamodt and Nygård, 1995, p. 193). Some have gone even further, arguing that the hierarchy is based on flawed assumptions and that it should be abandoned altogether (Frické, 2009). However, given that most information systems literature relies on these concepts, abandoning the hierarchy does not seem feasible. As a result, developing clear, consistent, and unambiguous definitions of the terms, their relationships, and their quality dimensions is imperative.

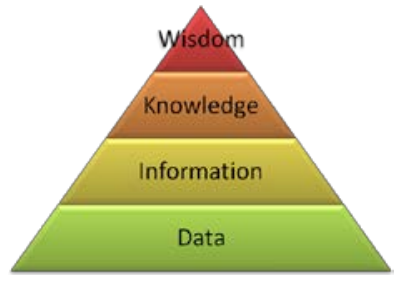

Figure 1: The DIKW Hierarchy - developed from (Rowley, 2007, p. 163)

\section{THEORETICAL EXPLORATION}

This section presents a theoretical exploration of the DIKW hierarchy and its quality dimension. Relevant terms and their relationships are contextualised within a semiotic framework.

\section{The DIKW Hierarchy}

Rowley (2007) identified a range of ambiguous and/or conflicting definitions, a subset of which is shown in Table 1, by examining a number of popular information systems and knowledge 
management textbooks. She attributed some of the earliest definitions to Ackoff (1989) and Zeleny (1987), paraphrasing Ackoff as follows: Wisdom is the ability to increase effectiveness. Intelligence is the ability to increase efficiency. Knowledge is know-how, and is what makes possible the transformation of information into instructions. Information provides answers to who, what, where and when questions. Data are defined as symbols that represent properties of objects, events and their environment. They are the products of observation (Rowley, 2007, p. 166).

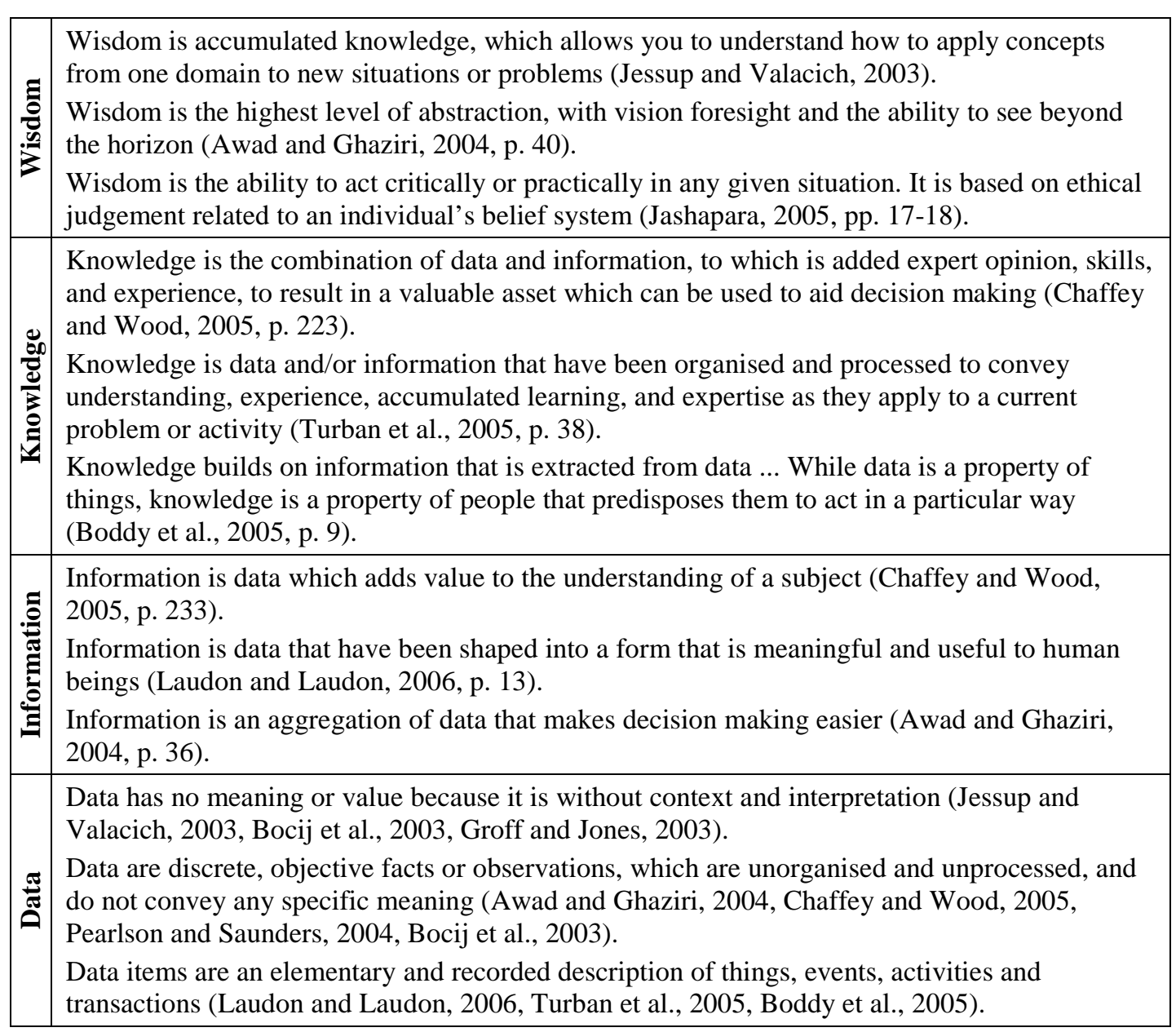

Table 1: Defining Data, Information, Knowledge, Wisdom: ambiguous and/or conflicting definitions developed from (Rowley, 2007, pp. 170-174)

\section{Data and Information}

In line with information theory (Shannon, 1948), data has been defined in terms of thermodynamic (physical) entropy, information in terms of Shannon (symbol) entropy, and knowledge in terms of cognitive (context) entropy (Boisot and Canals, 2004). As such, data can be considered as patterns with no meaning, information as interpreted data (i.e. data with meaning), and knowledge as “information incorporated in an agent's reasoning resources“ (Aamodt and Nygård, 1995, p. 196).

Whilst some of the above definitions seem to imply a linear relationship from data to wisdom, it has also been argued that data emerges from information and that information emerges from knowledge 
(Tuomi, 1999). In other words, data can be viewed as an external/objective (Zins, 2011) medium for communication and storage that is encoded from information by a sender and interpreted into information by a receiver (Kock et al., 1997). For instance, in the context of cryptography, encrypted information can be considered as data (Singh, 1999). But, more broadly, any binary representations that are stored on or communicated via a digital medium are referred to as data (Chen et al., 2009). On the other hand, information, which reduces uncertainty at the receiver (Shannon, 1948), can be viewed as a subjective/internal phenomenon (Zins, 2011). Others have argued that the concept of information is difficult to define due to its multidimensional nature (Beynon-Davies, 2009b).

\section{Knowledge}

From an epistemological perspective, philosophers and scientists have been struggling with the definition of knowledge for thousands of years (Alavi and Leidner, 2001). Similarly, it has been argued that knowledge management, the term that originated in US think tanks and management schools (Shields, 2001), is not clearly defined (Zhao et al., 2012) or distinguishable from related research areas (Gray and Meister, 2003). Nevertheless, literature explicates a number of dimensions, including that knowledge is a subjective/internal phenomenon (Zins, 2011), is context dependent, tacit, embedded, and socially constructed (Gosain, 2003, Burstein and Linger, 2003, Østerlie et al., 2012, Shields, 2001).

Whilst some authors discriminate between book and practical knowledge (Hara and Hew, 2007), others differentiate between knowledge of truths and knowledge of things (Russell, 1912). According to Russell, knowledge of truths (unlike knowledge of things) has an opposite (i.e. error), and all knowledge of truths has some degree of doubt (1912). Plato's original definition, “justified true belief“ (Plato), while sometimes challenged (Gettier, 1963, Nozick, 1981, Popper, 1979), is still largely accepted in the philosophical and scientific communities (Chisholm, 1982). Thus, it has been argued that "one can say 'He believes it, but it isn't so', but not 'He knows it, but it isn't so'“ (Wittgenstein et al., 1975). However, it needs to be noted that from the pragmatist perspective the adjective 'true' is the word applied to the beliefs which have been justified, and that justification is relative to an audience and to a range of truth candidates (Rorty, 1982). On the other hand, in line with the constructivist theory of knowledge (Piaget, 1977), it has also been argued that knowledge is subjective and constructed from personal interpretations (Martin et al., 2009). As such, a common view is that knowledge is the product of a synthesis in the mind of the knowing person (Leonardi and Treem, 2012), and exists only in his or her mind (Zins, 2011, Galliers and Newell, 2001, Linger and Warne, 2001). Given that knowledge always involves a knowing person (McDermott, 1999), it could be argued that "all knowledge is tacit, and what can be articulated and made tangible outside the human mind is merely information“ (Stenmark, 2002, p. 928). For instance, a bookcase or a computer may contain a lot of information, but no knowledge (McDermott, 1999).

\section{Wisdom}

Whilst the concept of wisdom has received very limited discussion in the information systems literature, it is generally defined in terms of value driven (ethical) intelligent behaviour (Dampney et al., 2002, Tuomi, 1999, Sternberg, 2000, Ackoff, 1989, Williams, 2001, Bierly et al., 2000, Rooney et al., 2008). Awareness of one's own cognitive limitations has also been described as a key characteristic of wisdom (Takahashi and Overton). In addition, psychologists have argued that wisdom is a personal (and not a group/social) quality, is a uniquely human trait, is a form of advanced cognitive and emotional development, is a rare quality, is experience driven (rather than innate), can be learned, increases with age, and can be measured (Jeste et al., 2010). Others have disputed the claim that it increases with age (Sternberg, 2005), have attempted to measure it (Jason et al., 2001), and have attempted to explain it in terms of neurobiological models (Meeks and Jeste, 2009). 


\section{The Quality Dimension}

Literature provides several definitions of quality (Hardie and Walsh, 1994), including "the capacity to satisfy wants“ (Edwards, 1968, p. 37), and "a subjective term for which each person or sector has its own definition“ (ASQ, 2002, p. 56). While Shewhart (1931) and Crosby (1979) argued that quality is represented by a difference between the preferred state and the actual state (thus, mainly defining quality as conformance to requirements), proposed dimensions of quality nowadays include: performance, features, reliability, conformance, durability, serviceability, aesthetics, and the like (Garvin, 1987). On the other hand, Feigenbaum (1986) and Juran (1974) defined quality in terms of customer satisfaction, where customer expectations can be seen as the preferred state and the concrete product or service received as the actual state.

In terms of the DIKW hierarchy, many researchers and practitioners use the terms data quality and information quality, which have been defined as "fitness for use" (Wang and Strong, 1996, p. 6), interchangeably (Madnick et al., 2009). More specifically, Wang and Strong (1996) defined data/information quality from users' perspective through a framework comprising four categories and 15 dimensions; these have now become generally accepted in literature (Madnick et al., 2009). Additionally, several other researchers have developed a range of data/information quality metrics (Pipino et al., 2002, Pipino et al., 2005, Redman, 1996) and assessment instruments (Lee et al., 2002, Price et al., 2008, Baškarada, 2010, Alkhattabi et al., 2011), which have been used to assess different aspects of data/information quality (Baškarada, 2011a).

Regarding knowledge quality, it has been argued that knowledge can be tested by analysing factual data and comparing the result with relevant theoretical predictions (Stumpf and McDonnell, 2003). In other words, the quality of knowledge is usually tested via the scientific method (Kosso, 2011).

Whilst the term wisdom quality does not appear in literature, it has been argued that "crucial to achieving wisdom is the capacity for reflexivity, which is the ability to understand the epistemic and ethical basis of our practice within its discursive domain“ (Rooney et al., 2008, p. 38).

\section{Semiotics}

Semiotics is a field of study that deals with the relationships between representations, intended meanings, and interpretations of signs and symbols (Baškarada, 2011b). Modern semiotics studies the construction of meanings with respect to communication as well as to the construction and maintenance of reality (Chandler, 2007, Beynon-Davies, 2009b). Semiotics is based on the supposition that the whole of human experience is an interpretive activity mediated and sustained by signs (Deely, 1990). As such, social activities are seen as being underpinned by sign-systems (organised collections of signs); e.g. spoken and body language (Beynon-Davies, 2007). In the context of semiotics, a datum is a "symbol or a set of symbols used to represent something" (BeynonDavies, 2009c, p. 173), and information is defined in terms of this concept of a symbol or sign (Beynon-Davies, 2009b).

Swiss linguist Ferdinand de Saussure (1983) and American logician and philosopher Charles Sanders Peirce (1998) are considered as the founders of semiotics (Chandler, 2007). Saussure defined a sign as an object with a meaning, comprising a signifier (signifiant) and a signified (signifie). Many semioticians, including Eco (1979), nowadays refer to the signifier and signified as sign-vehicle and meaning, respectively. The signifier carries the meaning and refers to the form that the sign takes. The signified refers to the concept the signifier represents; a mental activity of receiving a signifier represents the actual meaning that is carried. Thus, both the signifier and the signified were initially considered as psychological (abstract) concepts, which did not necessarily have to be physical. However, the signifier is nowadays commonly interpreted as the physical form of the sign (Chandler, 2007). Saussure also argued that signs only make sense in relation to other signs, and that there is no 
inherent relationship between the signifier and the signified (Saussure, 1983). As such, a sign has no absolute value; the value only emerges in relation to other signs.

Peirce defined semiosis as comprising three basic elements (Peirce, 1998). A sign (representamen) stands to somebody for something in some respect or capacity. An object is that referred to by the sign. The interpretant is an individual's comprehension of, and reaction to, the sign-object association. Comparable to Saussure's model, Peirce's semiosis elements do not refer to human subjects or physical objects, but to abstract entities (Eco, 1979). Since symbols are interpreted according to rules or habitual connections (Peirce, 1998), any interpretation is based on previous interpretations and will generate new interpretations (Eco, 1979). Thus, it may be impossible to determine the final and absolute meaning of signs.

\section{The Semiotic Ladder}

The American philosopher Charles W. Morris extended Peirce's semiotics by focusing on the relationships between signs and other signs, signs and objects, and signs and interpretants (Morris, 1938). As a result he proposed three complementary areas of study. Syntactics (or syntax) is the study of the formal or structural relations between signs-i.e. logic and grammar of sign systems. It deals with the physical form, rather than the content/meaning of signs (Beynon-Davies, 2007). Semantics is the study of the relations of signs to objects which they stand for. As such, semantics deals with rules that state the conditions under which signs apply to objects. Pragmatics is the study of the relation of signs to interpreters-for instance, pragmatics deals with rules which state the conditions in the interpreters under which the sign vehicle is interpreted as a sign (Fiordo, 1977). As such, pragmatics "links the issue of signs with that of intention" (Beynon-Davies, 2007, p. 316). However, according to Zemanek (1966), syntactics, semantics, and pragmatics are difficult, if not impossible, to consider in isolation from each other. Three additional levels (physical, empirical, and social) were latter added by Stamper (1973) to arrive at the semiotic ladder shown in Table 2. The physical level utilises the methods of physics and engineering to model signals, their sources, destinations, and routes over which they are transmitted. Empirics deals with coding and signal-to-error rates. And, the social level deals with values and action (Stamper et al., 2000).

\begin{tabular}{|l|l|}
\hline Level & Aspects of Representation \\
\hline Social & beliefs, expectations, commitments, contracts, social laws, culture, ... \\
\hline Pragmatic & intentions, communication, conversations, negotiations, speech acts, ... \\
\hline Semantic & meanings, propositions, validity, truth, signification, denotations, ... \\
\hline Syntactic & formal structure, language, logic, data, records, deduction, software, files, ... \\
\hline Empirical & pattern, variety, noise, entropy, channel capacity, codes, efficiency,, ... \\
\hline Physical & signals, physical distinctions, hardware, speeds, economics, laws of nature,... \\
\hline
\end{tabular}

Table 2: The Semiotic Ladder - adapted from (Falkenberg et al., 1998, p. 54)

\section{Semiotic DIKW Framework}

Figure 2 groups the semiotic ladder levels into three layers. The forma layer deals with the physical characteristics of signs. The informa layer deals with the content or meaning of signs. And, the performa layer deals with communication within social action.

Data are generated in the performa layer, reside in the forma layer, and are cognitively interpreted into information in the informa layer. For instance, due to his or her education and more extensive background knowledge, a doctor looking at a patient's blood test data should be able to infer more information compared with the patient looking at the same data. Endsley provides the following example: "[A]n experienced pilot will be able to classify observed aircraft into exact models (e.g., F18c vs. F-18d). ... A novice may not be able to make this level of classification and would 
consequently have less information from the same data input” (Endsley, 1995, p. 42). Therefore, we propose the following definitions:

Definition 1: Data are physical signs. They have no meaning because they reside outside of a human mind.

Definition 2: Information (or meaning) emerges through cognitive processing of data.

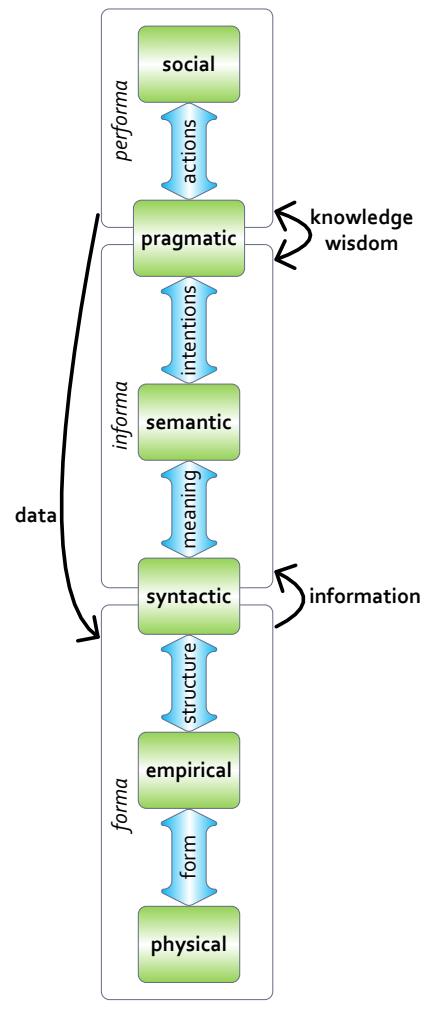

Figure 2: Semiotic DIKW Framework - adapted from (Beynon-Davies, 2011)

As such, words in a sentence (in the forma layer) may constitute high quality data (i.e. correct letters, spelling, grammar, etc.), but result in poor quality information when interpreted via the informa layer (e.g. a non-native speaker may not be able to understand a sentence as well, or not at all, compared to a native speaker). If we accept that data quality depends on the forma layer, then it chiefly depends on the encoding, storage, and communication protocols and technologies. From that point of view, data quality problems are primarily caused by engineering (software and hardware) flaws as well as by relevant human factors issues. For instance, buggy software may use incorrect data types, which may result in a loss of precision, or worse-e.g. a couple of integers may inadvertently be stored as Strings and, due to operator overloading, subsequent addition may lead to String concatenation and a nonsensical result/output. Similarly, data may be incorrectly encoded by individuals in the performa layer-e.g. through introduction of stochastic or systematic spelling mistakes. Hence, data quality should be assessed against predefined specifications for encoding, storage, and communication of data. Such protocols are developed by relevant communicative and engineering communities-i.e. by information system users and developers. Therefore, we propose the following definition:

Definition 3: Data quality is the gap between physical characteristics of signs and their specifications (the smaller the gap, the higher the quality). 
Given that information is cognitively generated and fundamentally relates to communication, this suggests that information quality needs to be evaluated in terms of a mapping (or a gap-analysis) between two corresponding cognitive states (i.e. sender's and receiver's). However, given the difficulties involved in comparing complex cognitive states, behaviouristic approaches may be preferred (Skinner, 2011). Such behaviouristic approaches to information quality assessment may involve evaluations of actions of the two persons (sender and receiver), which are principally reliant on the communicated information element(s). Variations in the resulting behaviour may indicate information quality problems. As Deming observed: “[T]he only communicable meaning of any word, specification, instruction, proclamation, or regulation is not what the writer thereof had in mind, but is instead, the result of application. How does the instruction work in practice? What happens?” (Deming, 2000, p. 70). For instance, poorly communicated information describing a location for a meeting (e.g. building and room number) may result in the receiver going to a different location compared to the sender; this divergence in behaviour implies an information quality problem. On the other hand, the quality of information that never has any impact on any behaviour naturally cannot be assessed using such approaches. However, from a behaviouristic perspective, it may be argued that such information has no observable effects and is therefore strictly speaking meaningless (Harré and Tissaw, 2005). As information quality depends on the intended use of the information, it only makes sense when contrasting multiple information elements/sets (i.e. better than, worse than). Alternatively, one would need to contrast a concrete information element/set with a hypothetical (ideal) element/set. The preceding discussion suggests that, similar to information, information quality is also subjective. As such, what is considered as high quality information by one person may be considered as low quality information by another. For instance, if someone's purpose is to deceive an audience then non-factual (inaccurate) information may be preferred by that person and considered as high quality. Therefore, we propose the following definition:

Definition 4: Information quality is information's fitness for purpose.

Adopting Rorty's (1982) argument that knowledge is relative to an audience and to a range of truth candidates, we may argue that interpreted data (i.e. information) may be validated via the performa layer into knowledge; knowledge also depends on the believing subject and social validation via the performa layer. In other words, if one does not believe some information, then it is not knowledge. Similarly, if one believes some information that is not recognised as truth by a relevant audience, then it is not knowledge either. Thus, knowledge only makes sense in relation to communities which have the conceptual tools to provide such validation. The difference between information and knowledge is that information does not require justification and social validation as it only relates to cognitive processing of data. In other words, information may be fictitious whereas knowledge has to be factual. As such, personal knowledge is a subset of personal information. Given that knowledge is relative to an audience (and considering that there may be multiple audiences with competing and perhaps incompatible views), similar to information quality, knowledge quality also only makes sense in relation to its purpose. However, information quality has a broader scope than knowledge quality as information's purpose could be to entertain (e.g. reading fiction or watching movies), or to influence the behaviour of others (e.g. propaganda). The question of truth has no relation to information or information quality; it is only relevant to knowledge. Therefore, we propose the following definitions:

Definition 5: Knowledge constitutes a person's beliefs which have been socially judged to be true.

Definition 6: Knowledge quality is knowledge's fitness for purpose.

Finally, if we accept the proposition that wisdom is also relative to an audience and a range of good decision (i.e. ethical truth) candidates, then we may argue that it also depends on the performa layer for validation. As such, wisdom depends on knowledge as well as social validation via the performa 
layer. And, given that there may be multiple audiences with competing and perhaps incompatible views, similar to knowledge quality, wisdom quality also only makes sense in relation to its purpose. Therefore, we propose the following definitions:

Definition 7: Wisdom constitutes a person's normative judgements which have been socially judged to be desirable.

Definition 8: Wisdom quality is wisdom's fitness for purpose.

\section{Proposed Definitions}

Drawing on the preceding theoretical discussion, we summarise the proposed definitions in Tables 3 and 4.

\begin{tabular}{|l|l|l|}
\hline Term & Definition & Example \\
\hline Data & $\begin{array}{l}\text { Data are physical signs. They have no } \\
\text { meaning because they reside outside } \\
\text { of a human mind. }\end{array}$ & $\begin{array}{l}\text { Characters in a book. } \\
\text { Bits in computer memory. } \\
\text { Street signs. }\end{array}$ \\
\hline Information & $\begin{array}{l}\text { Information (or meaning) emerges } \\
\text { through cognitive processing of data. }\end{array}$ & $\begin{array}{l}\text { Reading a book. } \\
\text { Watching a movie. }\end{array}$ \\
\hline Knowledge & $\begin{array}{l}\text { Knowledge constitutes a person's } \\
\text { beliefs which have been socially } \\
\text { judged to be true. }\end{array}$ & $\begin{array}{l}\text { The Sun is at the centre of our solar } \\
\text { system. }\end{array}$ \\
\hline Wisdom & $\begin{array}{l}\text { Wisdom constitutes a person's } \\
\text { normative judgements which have } \\
\text { been socially judged to be desirable. }\end{array}$ & We should reduce carbon emissions. \\
\hline
\end{tabular}

Table 3: Proposed Definitions of Data, Information, Knowledge, and Wisdom

\begin{tabular}{|l|l|l|}
\hline Term & Definition & Example \\
\hline $\begin{array}{l}\text { Data } \\
\text { Quality }\end{array}$ & $\begin{array}{l}\text { Data quality is the gap between } \\
\text { physical characteristics of signs and } \\
\text { their specifications (the smaller the } \\
\text { gap, the higher the quality). }\end{array}$ & $\begin{array}{l}\text { Low data quality: poor handwriting, } \\
\text { scratched CD/DVD, corrupt computer file, } \\
\text { etc. }\end{array}$ \\
\hline $\begin{array}{l}\text { Information } \\
\text { Quality }\end{array}$ & $\begin{array}{l}\text { Information quality is information's } \\
\text { fitness for purpose. }\end{array}$ & $\begin{array}{l}\text { If, ceteris paribus, following recipe A is } \\
\text { more effective at producing a tasty meal } \\
\text { than following recipe B, then, recipe A } \\
\text { constitutes higher quality information. }\end{array}$ \\
\hline $\begin{array}{l}\text { Knowledge } \\
\text { Quality }\end{array}$ & $\begin{array}{l}\text { Knowledge quality is knowledge's } \\
\text { fitness for purpose. }\end{array}$ & $\begin{array}{l}\text { If, ceteris paribus, Cognitive Behavioural } \\
\text { Therapy (CBT) is more effective at } \\
\text { reducing phobias than psychoanalytic } \\
\text { therapy, then, CBT constitutes higher } \\
\text { quality psychotherapeutic knowledge. }\end{array}$ \\
\hline $\begin{array}{l}\text { Wisdom } \\
\text { Quality }\end{array}$ & $\begin{array}{l}\text { Wisdom quality is wisdom's fitness } \\
\text { for purpose. }\end{array}$ & $\begin{array}{l}\text { If, ceteris paribus, increasing public } \\
\text { spending on education results in a superior } \\
\text { society than increasing public spending on } \\
\text { law enforcement, then, increasing public } \\
\text { spending on education constitutes higher } \\
\text { quality wisdom. }\end{array}$ \\
\hline
\end{tabular}

Table 4: Proposed Definitions of Data Quality, Information Quality, Knowledge Quality, and Wisdom Quality 


\section{EMPIRICAL EXPLORATION}

This section presents an empirical exploration of the DIKW hierarchy and the associated quality terms.

\section{Methodology}

Following Wittgenstein's ordinary language philosophy (Wittgenstein, 2001), we reviewed 20 online news articles for their uses of the terms data, information, knowledge, and wisdom (five articles for each term). Ordinary language philosophy considers traditional philosophical problems (in our case the DIKW hierarchy) as being caused by language misunderstandings, and argues that focusing on the uses of the terms in ordinary language may alleviate such misunderstandings (Boland et al., 2010). It "focuses on language not as an abstract system but in the actual context in which it functions in our daily life and activities" (Weinzweig, 1977, p. 118). As such, recent online news articles containing relevant terms were identified using Google News; each of the terms was searched for individually, and the top five articles were reviewed. Direct quotes containing relevant terms were extracted, and are presented in Table 5. Terms data quality, information quality, knowledge quality, and wisdom quality returned a very limited number of search results in Google News (256, 18, 0, and 0). As it appeared that data quality and information quality were used synonymously in those news articles, the quality related terms were excluded from this part of the empirical analysis.

At the same time, we also initiated and facilitated an online focus group discussion comprising 16 information systems experts (practitioners and academics), who were identified through the International Association for Information and Data Quality (IAIDQ). The participants were asked to define and discuss each term in the DIKW hierarchy as well as the associated quality terms. Overall, the focus group discussion resulted in 28 sequential responses totalling approximately 5,000 words.

Rooted in Wittgenstein's ordinary language philosophy, the data were subsequently analysed using Keywords-in-Context (KWIC) analysis, which is an appropriate analysis method when "there are specific words that are of interest to the researcher” (Leech and Onwuegbuzie, 2007, p. 566). As the name implies, KWIC involves searching for a particular keyword in a text and analysing its local meaning in relation to a fixed number of words immediately preceding and following it.

\section{RESULTS}

Direct quotes from the online articles, representing ordinary language uses of each of the terms, are shown in Table 5. Starting with data, one aspect that immediately stands out is the fact that all quotes seem to be using data in its plural form, thus, referring to it in terms of a set of data and not in terms of an individual datum. Considering information, it is difficult to identify any significant usage differences compared with the term data. As such, in the context of ordinary language, the results indicate that the terms data and information may potentially be interchangeable in most situation. With reference to knowledge, it is clear that all quotes refer to it in terms of a subject (i.e. a knowing person). The quotes refer to the knowledge of institutions, history, events, and things. As such, there appears to be a clear difference between knowledge on one hand and data and information on the other. Considering wisdom, there seems to be some overlap with knowledge. However, some of the quotes seem to imply that wisdom includes value judgments-e.g. political and religious wisdom as well as investment related wisdom.

Whilst the focus group discussion did not reach significant consensus, it did produce a rich data set representing a wide range of views from expert practitioners and academics. However, at least one participant was not convinced that reaching consensus was even possible, writing: 
Conventional wisdom says that President Obama is on the road to victory for re-election in 2012 (Dunn, 2011).

As Laurie Brlas, chief financial officer of Cliffs Natural Resources Inc. (CLF), prepared to

E announce a deal to buy a rival mining company this year, she was confident investors would eventually see the wisdom of her company's plan (Mider and McCracken, 2011).

Don't ignore ancient wisdom in predicting monsoon, drought (Gupta, 2011).

JFK's wisdom on religion and politics (LAT, 2011).

This time we review Warren Buffett's 1987 annual shareholder letter for his accumulated investing nuggets of wisdom (GF, 2011).

Knowledge on HST makes all the difference (Nichol, 2011).

To mark this event and to enhance the knowledge of the students of various courses of Father Muller Charitable Institutions, a new building with state-of-the-art facilities was built

(Margaret, 2011).

Know your Boston Bruins history? Brush up on some Stanley Cup knowledge, Beantown style (DMP, 2011).

Good knowledge of history is the mark of an educated and well-rounded person who is likely to be a good steward of the society where he or she lives and works (TSP, 2011).

Crowds keen for food knowledge at Cockermouth's Fell Gather (AAP, 2011).

A former expert-network consultant provided "to the decimal point" confidential financial information about technology companies to her hedge-fund clients in a "brazen insider-trading scheme," prosecutors said as her trial wound down on Thursday (WSJ, 2011).

E Vivek Kundra, the White House's first chief information officer, will leave in August after two and a half years in the post (Southall, 2011).

Google seeks to put users back in control of their online information with a service called Me on the Web that monitors your reputation (Claburn, 2011).

I The government must understand that Montreal's residents and off-island commuters need specific, detailed and daily information on the status of roads and bridges and what measures have been take to alleviate the congestion and help people get around (MG, 2011).

Latest traffic information from Transport NSW (Margaret, 2011).

Overland conceded that the force had failed to properly qualify the data for assaults in Melbourne's CBD, but he said there was no basis for a finding that the error of judgment was a case of 'conscious manipulation' (Ferguson, 2011).

The early estimate of a 0.9 per cent rise in the implicit price deflator for goods imports, a measure of price changes also noted with the March trade data, was confirmed by the ABS on 프 Wednesday (FairfaxDigital, 2011).

คี Australian stockmarket opens higher after positive US data (AAP, 2011).

Mr Nanterme said the world of data was now more volatile, more complex and expanding at speed. ... 'This plays in favour of having stronger analytics,' he said. 'Plus, there's just so much more data that you need to understand (Dearne, 2011).

This is encouraging data and a good first indication that the Human Papilloma Virus (HPV) vaccine is effective at preventing cervical cell abnormalities (BT, 2011).

Table 5: Ordinary Language Usages 
There is no answer but that doesn't mean that the contemplation isn't worthwhile. Only let's not contemplate with the idea that we're going to discover THE answer. ... Most of what is being put forward as definitions really amounts to opinions.

—Data Quality/Governance Professional

Other participants attempted to define the terms through asymmetric explanations; in other words, to define/explain information in terms of data, knowledge in terms of information, and wisdom in terms of knowledge. For instance:

"Information" and "data" from an academic perspective are different, as information is seen as using data in a given context.

—Data Quality and Master Data Professional

It all begins with data-it is the seed for information, wisdom and knowledge.

—Business Information Manager

Data is seen to be a raw diamond from the mine and once polished or placed on a ring it's information. And knowledge and wisdom are defined from information.

—Data Manager

Information is a collection of bits of data organized in a way that makes sense. ... Wisdom is very much an intangible thing. It's the collection of experience and knowledge that a person builds up over time which allows them to make good decisions.

—Data Governance Architect

I ... would say that knowledge is the collection of a body of data or information. Wisdom is the ability to apply thought processes to make sense of available data, information and/or knowledge.

—Business Intelligence Professional

As can be seen, many definitions/explanations relied on analogies and metaphors like "data is seen to be a raw diamond" and "data ... is the seed for information". As such, they were not very specific and thus open to interpretation. Even "information is seen as using data in a given context" does not clearly specify the nature of the context and its specific relation to the user, data, and information.

Defining data also proved challenging. Some proposed definitions included the following:

Data, as we speak of it, is a more-or-less direct representation of circumstance.

—Data Quality Analyst

[Data is] a representation of reality.

—CRM and MDM Professional

Data has been defined as "raw facts" and information is "data in context".

—Enterprise Information Management Professional

Data is just a collection of instantaneous observations. I weigh $170 \mathrm{lbs}$. The car I see is red. There are 10 people standing in line at Starbucks at 2pm on a Tuesday. That is data. Data by itself is not meaningful. It is the fundamental building block for everything above it.

—Data Governance Architect

The quote above states that data by itself is not meaningful, yet it provides examples like "The car I see is red" and "There are 10 people standing in line at Starbucks at 2pm on a Tuesday". Are these instantaneous observations not meaningful? It turned out the discussion of the quality related terms provided additional context and shed more light on the basic terms and their relationships. Nevertheless, some participants argued that there was no real difference between data and information quality. For instance: 
The terms "data quality" and "information quality" are indeed often used synonymously. ... Experienced from my daily work with people from business and IT staff I don't think people in general care about the difference between "data quality" and "information quality".

—Data Quality and Master Data Professional

On the other hand, others argued:

I think that "data quality" and information quality" are related, but not really interchangeable. -Enterprise Information Management Professional Information quality depends highly on data quality.

—Data Governance Architect

One participant explained the difference in terms of an internal versus external view:

I don't think there is much dispute that we can distinguish between data and information ... I approach it from an internal versus external view. I see data quality as the internal view in an enterprise focused on whether the data ... held in the information systems meets the specifications that have been defined for it. In another sense DQ is the engineering view of "does the data meet the specifications?". On the other hand I see information quality as more of an external view of users of the information products produced by the system.

—Professor of Information Science

An example provided by another participant further clarified this potential distinction:

Now ... we can ... conclude that the data comprising the content of this thread is high quality (i.e. the characters making up the words, sentences and paragraphs) but the information (our thoughts constructed of the data) is low quality...

—Customer Relationship Management and Master Data Management Professional

Another participant elaborated on the relationship between data quality and information by arguing:

I've come to the conclusion that Information is high quality Data. ... If the customer wants to be informed (wants information), and high quality data should do just that, then they are one and the same. Put another way, if data is not high quality then it is not information. Is "high quality use of information" the same as knowledge or wisdom?

—Data Strategy and Standards Professional

However, another participant argued:

Quality is the combination of the objective and subjective ... We spend way too much time on the objective, declining to consider the subjective as too squishy or unmeasurable.

—Customer Relationship Management and Master Data Management Professional

Defining knowledge quality and wisdom quality proved much more difficult. One of the participants explained:

If I used "knowledge quality" or "wisdom quality" I guess people will look at me as pretentious.

—Data Quality and Master Data Professional

Compared with the news articles, which did not seem to differentiate between data and information, the focus group discussion did attempt to draw a distinction between these two terms. This may be explained through the fact that the focus group comprised information systems specialists; nevertheless, they did not manage to reach significant consensus. While even less consensus regarding the terms knowledge and wisdom was reached, it was noted that they depend on data and information (e.g. knowledge is the collection of a body of data or information), and that wisdom should help people make good decisions. 


\section{CONCLUDING REMARKS}

In this paper, we aimed to comprehensively review and provide a high-level synthesis of the literature on the DIKW hierarchy, its constituent elements, and its quality dimension. Furthermore, we attempted to ground the hierarchy in a semiotic framework with a view of providing clear and consistent definitions (see Tables 3 and 4). Whilst several researchers have already critically reviewed the DIKW hierarchy and its constituent elements (Rowley, 2007, Frické, 2009, Zins, 2011), building on Falkenberg et al. (1998) this paper makes a theoretical contribution by explicitly grounding the hierarchy in the literature on semiotics (Beynon-Davies, 2007, 2009c, b, a, 2011, Morris, 1938, Peirce, 1998, Saussure, 1983), and by exploring the relationship between the hierarchy and its quality dimension. The paper also offers an empirical contribution by providing further evidence for the lack of consistency in how the relevant terms are used in every-day language as well as by information systems experts.

\section{ACKNOWLEDGEMENT}

The authors would like to thank two anonymous reviewers for their constructive comments provided on earlier drafts of this paper.

\section{REFERENCES}

Aamodt, A. \& Nygård, M. 1995. Different roles and mutual dependencies of data, information, and knowledge - an AI perspective on their integration. Data and Knowledge Engineering, 16, 191-222.

AAP. 2011. Australian stockmarket opens higher after positive US data [Online]. Available: http://www.theaustralian.com.au/business/markets/australian-stockmarket-opens-higher-afterpositive-us-data/story-e6frg916-1226076957825 [Accessed 17 June 2011].

Ackoff, R. L. 1989. From data to wisdom. Journal of Applied Systems Analysis, 16, 3-9.

Alavi, M. \& Leidner, D. E. 2001. Review: Knowledge management and knowledge management systems: conceptual foundations and research issues. MIS Q., 25, 107-136.

Alkhattabi, M., Neagu, D. \& Cullen, A. 2011. Assessing information quality of e-learning systems: a web mining approach. Comput. Hum. Behav., 27, 862-873.

Allen, J. P. 2000. Information systems as technological innovation. Information Technology \& People, 13, 210-221.

ASQ 2002. Quality Glossary. Quality Progress, 35.

Awad, E. M. \& Ghaziri, H. M. 2004. Knowledge Management, Upper Saddle River, NJ, Pearson Education International.

Baškarada, S. 2010. Information Quality Management Capability Maturity Model, Wiesbaden, Vieweg+Teubner.

Baškarada, S. 2011a. How Spreadsheet Applications Affect Information Quality. Journal of Computer Information Systems, 51, 77-84.

Baškarada, S. 2011b. Towards a Semiotic Information Position Framework for Network Centric Warfare. 16th International Command and Control Research and Technology Symposia (ICCRTS). Québec City, Canada.

Beynon-Davies, P. 2007. Informatics and the Inca. International Journal of Information Management, 27, 306-318. 
Beynon-Davies, P. 2009a. The 'language' of informatics: The nature of information systems. International Journal of Information Management, 29, 92-103.

Beynon-Davies, P. 2009b. Neolithic informatics: The nature of information. International Journal of Information Management, 29, 3-14.

Beynon-Davies, P. 2009c. Significant threads: The nature of data. International Journal of Information Management, 29, 170-188.

Beynon-Davies, P. 2011. In-formation on the prairie: Signs, patterns, systems and prairie dogs. International Journal of Information Management, 31, 307-316.

Bierly, P. E., Kessler, E. H. \& Christensen, E. W. 2000. Organizational learning, knowledge and wisdom. Journal of Organizational Change Management, 13, 595-618.

Bocij, P., Chaffey, D., Greasley, A. \& Hickie, S. 2003. Business Information Systems: Technology, Development and Management for the e-Business, Harlow, FT Prentice Hall.

Boddy, D., Boonstra, A. \& Kennedy, G. 2005. Managing Information Systems: an Organizational Perspective, Harlow, FT Prentice Hall.

Boisot, M. \& Canals, A. 2004. Data, information and knowledge: have we got it right? Journal of Evolutionary Economics, 14, 43-67.

Boland, R. J., Newman, M. \& Pentland, B. T. 2010. Hermeneutical exegesis in information systems design and use. Information and Organization, 20, 1-20. Available: http://www.sciencedirect.com/science/article/pii/S1471772709000323.

BT. 2011. Cancer vaccine data 'encouraging' [Online]. Available: http://www.belfasttelegraph.co.uk/news/local-national/uk/cancer-vaccine-data-encouraging16012890.html [Accessed 17 June 2011].

Burstein, F. \& Linger, H. 2003. Supporting post-Fordist work practices: A knowledge management framework for supporting knowledge work. Information Technology \& People, 16, 289-305.

Chaffey, D. \& Wood, S. 2005. Business Information Management: Improving Performance Using Information Systems, Harlow, FT Prentice Hall.

Chandler, D. 2007. Semiotics: The Basics, Routledge.

Chen, M., Ebert, D., Hagen, H., Laramee, R. S., Liere, R. v., Ma, K.-L., Ribarsky, W., Scheuermann, G. \& Silver, D. 2009. Data, Information, and Knowledge in Visualization. IEEE Computer Graphics and Applications, 29, 12-19.

Chisholm, R. M. 1982. The Foundations of Knowing, Minneapolis, University of Minnesota Press.

Claburn, T. 2011. Google Suggests Googling Yourself [Online]. Available: http://www.informationweek.com/news/internet/google/230800083 [Accessed 17 June 2011].

Claver, E., Llopis, J., González, M. R. \& Gascó, J. L. 2001. The performance of information systems through organizational culture. Information Technology \& People, 14, 247-260.

Crosby, P. 1979. Quality is Free, New York, McGraw-Hill.

Dampney, K., Busch, P. \& Richards, D. 2002. The Meaning of Tacit Knowledge. Australasian Journal of Information Systems, 10, 3-13. Available: http://dl.acs.org.au/index.php/ajis/article/view/438 [Accessed Jan 2012].

Dearne, K. 2011. SAS, Accenture in data analytics alliance [Online]. Available: http://www.theaustralian.com.au/australian-it/sas-accenture-in-data-analytics-alliance/storye6frgakx-1226076874647 [Accessed 17 June 2011].

Deely, J. 1990. Basics of Semiotics, Bloomington, IN, Indiana University Press.

Deming, W. E. 2000. Out of the Crisis, Mit Press. 
DMP. 2011. Know your Boston Bruins history? Brush up on some Stanley Cup knowledge, Beantown style [Online].

Available:

http://middletownpress.com/articles/2011/06/16/sports/doc4dfaaf7cc4a9b828770607.txt

[Accessed 17 June 2011].

Dunn, C. W. 2011. DUNN: Conventional wisdom that says Nobama [Online]. Available: http://www.washingtontimes.com/news/2011/jun/16/conventional-wisdom-that-says-nobama/ [Accessed 17 June 2011].

Eco, U. 1979. A Theory of Semiotics, Indiana University Press.

Edwards, C. D. 1968. The Meaning of Quality. Quality Progress.

Endsley, M. R. 1995. Toward a Theory of Situation Awareness in Dynamic Systems. Human Factors: The Journal of the Human Factors and Ergonomics Society, 37, 32-64. Available: http://hfs.sagepub.com/content/37/1/32.abstract.

FairfaxDigital. 2011. Preview of next week's economic data [Online]. Available: http://www.tradingroom.com.au/apps/view_breaking_news_article.ac?page=/data/news_resear ch/published/2011/6/168/catf_110617_141200_5632.html [Accessed 17 June 2011].

Falkenberg, E. D., Hesse, W., Lindgreen, P., Nilsson, B. E., Oei, J. L. H., Rolland, C., Stamper, R. K., Assche, F. J. M. V., Verrijn-Stuart, A. A. \& Voss, K. 1998. A Framework of Information System Concepts: The FRISCO Report, The Netherlands, Department of Computer Science, University of Leiden.

Fayyad, U. M., Piatetsky-Shapiro, G. \& Smyth, P. 1996. From data mining to knowledge discovery: an overview. AI Magazine, 17, 37-54.

Feigenbaum, A. V. 1986. Total Quality Control, New York, NY, McGraw-Hill.

Ferguson, J. 2011. 'Widespread flaws' in crime data collection [Online]. Available: http://www.theaustralian.com.au/national-affairs/widespread-flaws-in-crime-datacollection/story-fn59niix-1226076689823 [Accessed 17 June 2011].

Fiordo, R. A. 1977. Charles Morris and the Criticism of Discourse, John Benjamins Publishing Company.

Frické, M. 2009. The knowledge pyramid: a critique of the DIKW hierarchy. Journal of Information Science, 35, 131-142.

Galliers, R. \& Newell, S. 2001. Back to the Future: From Knowledge Management to Data Management. Proceedings of ECIS. Bled, Slovenia.

Garvin, D. 1987. Competing on the Eight Dimensions of Quality. Harvard Business Review, 65, 101109.

Gettier, E. 1963. Is Justified True Belief Knowledge? Analysis, 23, 121-23.

GF. 2011. In Search Of Investment Wisdom - A Review Of Berkshire Hathaway's 1987 Annual Shareholder Letter [Online]. Available: http://www.gurufocus.com/news/136560/in-search-ofinvestment-wisdom--a-review-of-berkshire-hathaways-1987-annual-shareholder-letter [Accessed 17 June 2011].

Gosain, S. 2003. Issues in designing personal knowledge exchanges: First movers analyzed. Information Technology \& People, 16, 306-325.

Gray, P. H. \& Meister, D. B. 2003. Introduction: fragmentation and integration in knowledge management research. Information Technology \& People, 16, 259-265.

Groff, T. R. \& Jones, T. P. 2003. Introduction to Knowledge Management: KM in Business, Amsterdam, Butterworth Heinemann. 
Gupta, S. 2011. Don't ignore ancient wisdom in predicting monsoon, drought [Online]. Available: http://articles.economictimes.indiatimes.com/2011-06-17/news/29670079_1_rainfallforecasts-monsoon [Accessed 17 June 2011].

Hara, N. \& Hew, K. F. 2007. Knowledge-sharing in an online community of health-care professionals. Information Technology \& People, 20, 235-261.

Hardie, N. \& Walsh, P. 1994. Toward a Better Understanding of Quality. International Journal of Quality \& Reliability Management, 11, 53-63.

Harré, R. \& Tissaw, M. A. 2005. Wittgenstein And Psychology: A Practical Guide, Ashgate Publishing Company.

Hasan, H. 2002. Information Systems as Dialectic, Tool - Mediated Activity. Australasian Journal of Information Systems, 10, 30-39. Available: http://dl.acs.org.au/index.php/ajis/article/view/441 [Accessed Jan 2012].

Jashapara, A. 2005. Knowledge Management: an Integrated Approach, Harlow, FT Prentice Hall.

Jason, L. A., Reichler, A., King, C., Madsen, D., Camacho, J. \& Marchese, W. 2001. The Measurement of Wisdom: A Preliminary Effort. Journal of Community Psychology, 29, 585598.

Jessup, L. M. \& Valacich, J. S. 2003. Information Systems Today, Upper Saddle River, NJ, Prentice Hall.

Jeste, D., Ardelt, M., Blazer, D. \& Meeks, T. 2010. Expert Consensus on Characteristics of Wisdom: A Delphi Method Study. Gerontologist, 50, 668-680.

Juran, J. M. 1974. Quality Control Handbook, New York, NY,, McGraw-Hill.

Kallinikos, J. 2006. Information out of information: on the self-referential dynamics of information growth. Information Technology \& People, 19, 98-115.

Kamhawi, E. M. 2010. The three tiers architecture of knowledge flow and management activities. Information and Organization, 20, 169-186. Available: http://www.sciencedirect.com/science/article/pii/S1471772710000321 [Accessed 2010/10//].

Kock, N. F., McQueen, R. J. \& Corner, J. L. 1997. The nature of data, information and knowledge exchanges in business processes: implications for process improvement and organizational learning. Learning Organization, 4, 70-80.

Kosso, P. 2011. A Summary of Scientific Method, Springer.

LAT. 2011. JFK's wisdom on religion and politics; Secure Communities in California; the rights and protections of marriage [Online]. Available: http://www.latimes.com/news/opinion/letters/lale-0617-friday-20110617,0,3661883.story [Accessed 17 June 2011].

Laudon, K. C. \& Laudon, J. P. 2006. Management Information Systems: Managing the Digital Firm, Upper Saddle River, NJ, Pearson Prentice Hall.

Lee, Y., Strong, D., Kahn, B. \& Wang, R. 2002. AIMQ: A Methodology for Information Quality Assessment. Information Management, 40, 133-146.

Leech, N. \& Onwuegbuzie, A. 2007. An array of qualitative data analysis tools: A call for data analysis triangulation. School Psychology Quarterly, 22, 557-584.

Leonardi, P. M. \& Treem, J. W. 2012. Knowledge management technology as a stage for strategic self-presentation: Implications for knowledge sharing in organizations. Information and Organization, $22, \quad 37-59 . \quad$ Available: http://www.sciencedirect.com/science/article/pii/S1471772711000510. 
Linger, H. \& Warne, L. 2001. Making the Invisible Visible: modelling social learning in a knowledge management context. Australasian Journal of Information Systems, 9, 56-66. Available: http://dl.acs.org.au/index.php/ajis/article/view/214/186 [Accessed Jan 2012].

Madnick, S. E., Wang, R. Y., Lee, Y. W. \& Zhu, H. 2009. Overview and Framework for Data and Information Quality Research. ACM Journal of Data and Information Quality, 1.

Margaret, J. 2011. Latest traffic Information from Transport NSW [Online]. Available: http://blogs.abc.net.au/nsw/2011/06/latest-traffic-information-fromtransport-nsw.html [Accessed 17 June 2011].

Martin, C., Philp, W. \& Hall, W. 2009. Temporal Convergence for Knowledge Management. Australasian Journal of Information Systems, 15, 133-148. Available: http://dl.acs.org.au/index.php/ajis/article/view/207/480 [Accessed Jan 2012].

McDermott, R. 1999. Why Information Technology Inspired But Cannot Deliver Knowledge Managennent. California Management Journal, 41, 103-117.

Meeks, T. \& Jeste, D. 2009. Neurobiology of Wisdom. Arch Gen Psychiatry, 66, 355-365.

MG. 2011. The Gazette's View: On roads and bridges, we need fixes - and information [Online]. Available:

http://www.montrealgazette.com/Gazette+View+roads+bridges+need+fixes+information/4960 712/story.html [Accessed 17 June 2011].

Mider, Z. R. \& McCracken, J. 2011. Record Stock Gains for Acquirers Defy Wall Street Selloff Wisdom [Online]. Available: http://www.bloomberg.com/news/2011-06-16/record-stockgains-for-buyers-defy-wall-street-wisdom-on-takeover-selloffs.html [Accessed 17 June 2011].

Morris, C. W. 1938. Foundations of the Theory of Signs, Chicago, Chicago University Press.

Nichol, A. 2011. Knowledge on HST makes all the difference [Online]. Available: http://www.coastreporter.net/article/20110617/SECHELT0302/306179970/1/sechelt/knowledge-on-hst-makes-all-the-difference [Accessed 17 June 2011].

Nozick, R. 1981. Philosophical explanations, Harvard University Press.

O'Donovan, B. \& Roode, D. 2002. A Framework for Understanding the Emerging Discipline of Information Systems. Information Technology \& People, 15, 26-41.

Østerlie, T., Almklov, P. G. \& Hepsø, V. 2012. Dual materiality and knowing in petroleum production. Information and Organization, 22, 85-105. Available: http://www.sciencedirect.com/science/article/pii/S1471772712000024.

Pearlson, K. E. \& Saunders, C. S. 2004. Managing and Using Information Systems: a Strategic Approach, New York, Wiley.

Peirce, C. S. 1998. The Essential Peirce, Volume 2: Selected Philosophical Writings, 1893-1913, Indiana University Press.

Piaget, J. 1977. The Development of Thought: Equilibrium of Cognitive Structures, NY, Viking Press.

Pipino, L., Lee, Y. \& Wang, R. 2002. Data Quality Assessment. Communications of the ACM, 45, 211-218.

Pipino, L., Wang, R., Kopcso, D. \& Rybolt, W. 2005. Developing Measurement Scales for DataQuality Dimensions. In: Wang, R. Y., Pierce, E. M., Madnick, S. E. \& Fisher, C. W. (eds.) Information Quality. Armonk, NY: M.E. Sharpe.

Plato Theaetetus

Popper, K. R. 1979. Objective knowledge: an evolutionary approach, Clarendon Press. 
Price, R., Neiger, D. \& Shanks, G. 2008. Developing a Measurement Instrument for Subjective Aspects of Information Quality. Communications of the Association for Information Systems, 22, 49-74.

Redman, T. C. 1996. Data Quality for the Information Age, Boston, Artech House.

Rooney, D., Hearn, G. \& Ninan, A. 2008. Handbook on the Knowledge Economy, Edward Elgar.

Rorty, R. 1982. Consequences Of Pragmatism: Essays 1972-1980, University of Minnesota Press.

Rowley, J. 2007. The wisdom hierarchy: representations of the DIKW hierarchy. Journal of Information Science, 33, 163-180.

Russell, B. 1912. The Problems of Philosophy, Feedbooks.

Saussure, F. D. 1983. Course in General Linguistics, London, Duckworth.

Shannon, C. 1948. A Mathematical Theory of Communication. Bell System Technical Journal, 27, 379-423 \& 623-656.

Shewhart, W. A. 1931. Economic Control of Quality of Manufactured Product, New York, NY, van Nostrand.

Shields, R. 2001. The New 'Knowledge Speak': the implications of contested definitions of knowledge and information. Australasian Journal of Information Systems, 8, 142-149. Available: http://dl.acs.org.au/index.php/ajis/article/view/250/221 [Accessed Jan 2012].

Singh, S. 1999. The code book: the science of secrecy from ancient Egypt to quantum cryptography, NewYork, NY, Anchor Books.

Skinner, B. F. 2011. About Behaviorism, Knopf Doubleday Publishing Group.

Southall, A. 2011. Information Officer Is Leaving [Online]. Available: http://www.nytimes.com/2011/06/17/us/politics/17brfs-Kundra.html?_r=2 [Accessed 17 June 2011].

Stamper, R., Liu, K., Hafkamp, M. \& Ades, Y. 2000. Understanding the Roles of Signs and Norms in Organisations. Journal of Behaviour \& Information Technology, 19, 15-27.

Stamper, R. K. 1973. Information in Business and Administrative Systems, London, Batsford.

Stenmark, D. 2002. Information vs. Knowledge: The Role of intranets in Knowledge Management. Proceedings of the 35th Hawaii International Conference on System Sciences. Hawaii, USA.

Sternberg, R. 2000. Wisdom as a Form of Giftedness. Gifted child quarterly, 44, 252 - 260.

Sternberg, R. 2005. Older but not wiser? The relationship between age and wisdom. Ageing International, 30, 5-26. Available: http://dx.doi.org/10.1007/BF02681005.

Stumpf, S. \& McDonnell, J. 2003. Data, Information and Knowledge Quality in Retail Security Decision Making. 3rd International Conference on Knowledge Management (IKNOW’03). Graz.

Takahashi, M. \& Overton, W. Cultural Foundations of Wisdom: An Integrated Developmental Approach. In: Sternberg, R. J. \& Jordan, J. (eds.) A handbook of wisdom: psychological perspectives.

TSP. 2011. OUR VIEW: Disturbing trend: Students with poor knowledge of history [Online]. Available: http://www.thestarpress.com/article/20110616/OPINION01/106160318 [Accessed 17 June 2011].

Tuomi, I. 1999. Data is more than knowledge: implications of the reversed knowledge hierarchy for knowledge management and organizational memory. In: HICSS-32. Proceedings of the 32nd Annual Hawaii International Conference on System Sciences, 5-8 Jan Maui, HI , USA. 
Turban, E., Rainer, R. K. \& Potter, R. E. 2005. Introduction to Information Technology, New York, Wiley.

Wang, R. Y. \& Strong, D. M. 1996. Beyond Accuracy: What Data Quality Means to Data Consumers. Journal of Management Information Systems, 12, 5-34.

Weinberger, D. 2010. The Problem with the Data-Information-Knowledge-Wisdom Hierarchy. HBR Blog Network [Online]. Available: http://blogs.hbr.org/cs/2010/02/data is to_info_as info_is not.html [Accessed 18 Feb 2013].

Weinzweig, M. 1977. PHENOMENOLOGY AND ORDINARY LANGUAGE PHILOSOPHY. Metaphilosophy, 8, 116-146. Available: http://dx.doi.org/10.1111/j.14679973.1977.tb00267.x.

Williams, M. C. 2001. Ethics in Research. Australasian Journal of Information Systems, 8, 68-74. Available: http://dl.acs.org.au/index.php/ajis/article/viewFile/244/214 [Accessed Jan 2012].

Wittgenstein, L. 2001. Philosophical Investigations, Carlton, VIC, Australia, Wiley-Blackwell.

Wittgenstein, L., Anscombe, G. E. M. \& Wright, G. H. 1975. On certainty, Blackwell.

WSJ. 2011. First Expert-Network Trial Winds Down [Online]. Available: http://online.wsj.com/article/SB10001424052702303499204576389873708709788.html [Accessed 17 June 2011].

Zeleny, M. 1987. Management support systems: towards integrated knowledge management. Human Systems Management, 7, 59-70.

Zemanek, H. 1966. Semiotics and Programming Languages. Communications of the ACM, 9, 139143.

Zhao, J., de Pablos, P. O. \& Qi, Z. 2012. Enterprise knowledge management model based on China's practice and case study. Computers in Human Behavior, 28, 324-330. Available: http://www.sciencedirect.com/science/article/pii/S0747563211002093.

Zins, C. 2011. Conceptual Approaches for Defining Data, Information, and Knowledge. Journal of the American Society for Information Science and Technology, 58, 479-493. 